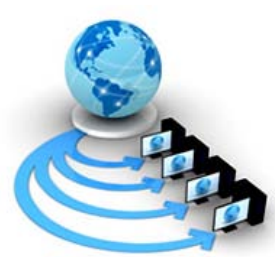

Volume 8, No. 9, November-December 2017

International Journal of Advanced Research in Computer Science

RESEARCH PAPER

Available Online at www.ijarcs.info

\title{
APPLYING CASE STUDY BASED APPROACH AS PART OF PROBLEM BASED LEARNING IN STUDENT DEVELOPMENT
}

\author{
Dr. Nirali Honest \\ Assistant Professor, \\ CMPICA, CHARUSAT,India
}

\begin{abstract}
In the current era, the frequency of changes is highly increased. What we teach to students as the recent technology may change soon when they pass out and join the job environment. What remain constant are the concepts and basic foundation courses of every program. As part of changes occurring to speedily it is mandatory to develop self learning and problem solving skills in the students as part of the learning process. This paper focuses on how case study based approach can be used to help the students to learn in group and solve the problems as and when they occur.
\end{abstract}

Keywords: Case study based learning, problem solving ability, self learning.

\section{INTRODUCTION}

In traditional classroom teaching, sometimes it happens that faculty members are poor lecturers or students are poor participants in the lecture, this mode of teaching creates a passive environment in the classroom. This derives a habit of memorization without understanding which is harmful for the overall understanding and application of the concepts learnt in the classroom [1].

ICT stands for Information Communication and Technology, each word has a meaning,Information is basically data, which with the addition of learning becomes knowledge. In other words, learning which is based on the capacity to find, access, apply and transform information into new knowledge.Important abilities which learners require to make this transformation are often called information literacy abilities and include awareness of the need for information, the ability to critically analyze information and evaluate its usefulness and ultimately to be able to apply the information, turning it into knowledge. Communication is that simple act of dialogue between peoples and cultures that takes on a new dimension when combined with 'information' and 'technology'. Technology is not strictly limited to the Internet and includes simpler technology such as CD ROM, video, television etc. although the term 'information technology' does imply the use of the Internet and telecommunication networks. Certainly in educational practices, information technology falls into two parts: computer technology which is computer based courses, computerized tests, word processors, graphics software, spreadsheets, databases and presentation software;telecommunications software which offers distance courses, distributed educational resources, e-mail, videoconferencing, bulletin boards and whiteboards.The education teaching and learning has been affected by use of ICTs, which has a great impact on the learning habits of students [2]. It has been researched that it has benefits to the quality of education [3].Good teaching is not simply adding technology to the existing teaching and content domain rather it should cause the representation of new concepts and requires developing sensitivity to the dynamic, transactional relationship between the three components of knowledge which are Content, Technology and Pedagogy. There has to be a tight synchronization between these three components to be effective in teaching and learning. The current students are called Google era students which have certain characteristics as below,

\subsection{Characteristics of Google era students}

- Students have no reading habits.

- $\quad$ Students have more logic and reasoning.

- They don't accept the things until they are convinced.

- They are more focused and have very clear goals.

\subsection{Benefits and challenges in implementing case study based learning}

The case study teaching method is a highly adaptable style of teaching that involves problem-based learning and promotes the development of analytical skills [6].Similarly, case studies facilitate interdisciplinary learning and can be used to highlight connections between specific academic topics and real-world societal issues and applications [7][8].This has been reported to increase student motivation to participate in class activities, which promotes learning and increases performance on assessments [9][10][11][12].

\section{Benefits of the case study based approach}

o Case study teaching increases student perception of learning gains related to core course objectives

o Student perceptions of learning gains resulting from case study teaching are positively correlated to increased performance on examinations, but independent of case study author

o Teaching with case studies improves performance on learning assessments, independent of case study origin 
Challenges of the case study based approach

o Course material has to be complete and adequate with simplicity, so students can easily understand

o The books, notes,presentation, etc. all learning resources has to be available all the time so the students can access them any time.

o Data collection and analysis of case study is time consuming and it requires the review of work to be done at least thrice before the final submission.

o Student population is more than it become more time consuming in terms of managing the records of students, their work and eth evaluation of work.

\section{PROBLEMS WITH CONCEPTUAL SUBJECTS}

There are several reasons for using the PBL approach in the student development

- Traditional lectures can help very less in students to remember and recall whatever they have learnt.

- Whatever the students have learnt during the curriculum they apply very less to solve the real world problems.

- Faculty conducting the course must find some mechanisms to create interest and involvement of students in the course.

- During the process of PBL students can apply the previous knowledge they have gained while forming the solution for current problem. What is learnt earlier can be helpful later in deriving the solution. Students can learn on how to elaborate on the solutions they have obtained during the PBL process.

PBL is an instructional methodology which is used over 30 years successfully and continues to gain acceptance in multiple disciplines [13]. The approach of PBL motivates to self-learning practice, and then apply the knowledge to solve the problem, this helps the students to gain understanding, apply logic and reasoning in solving the problem, develops learning skills, makes them to work cooperatively and collaboratively [14].

PBL can be applied in two ways [15], Problem Stimulated PBL and Student Centered PBL. The first approach uses role relevant problems with the emphasis to focus on development of domains-specifics skills, problem specific skills which can help to derive knowledge specific to domain.

\section{CASE STUDY BASED LEARNING}

I have taken the example of case study for one of the subjects that I teach, Software Quality Assurance. Here I have asked students to apply manual or automated testing, and I gave them a template in which they have to submit the case study.

Steps to apply the case study based learning

- Explain what is expected from the case study for the given subject

- Team size of three to four members is formed.

- Students can select the members of team by their own.
- They need to decide the title of work and submit in the first review

- They need to submit the scope and details of work in the second review

- They need to start implementing and show the working model for atleast two features of the total work decided.

- They need to submit the application and the documented work for the application using MOODLE - LMS used for interaction with the students.

They have to work in team and submit the assigned work, by doing this exercise they share the ideas and views which help them understand and apply the concept in the given domain.

\subsection{Example of case study}

\subsubsection{Manual case study example}

The students decide the group and give definitions to work on , they have to give review of work at the given intervals. Figure 1. Shows the cover page of the work of one group.

\section{Topic:}

\section{Notepad in java (unit Testing)}

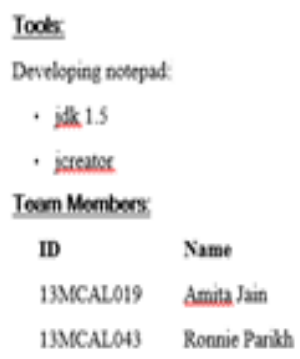

Fig 1. Snapshot of cover page of case study

Figure 2 shows the working application and Figure 3 shows the working of "Find" functionality.

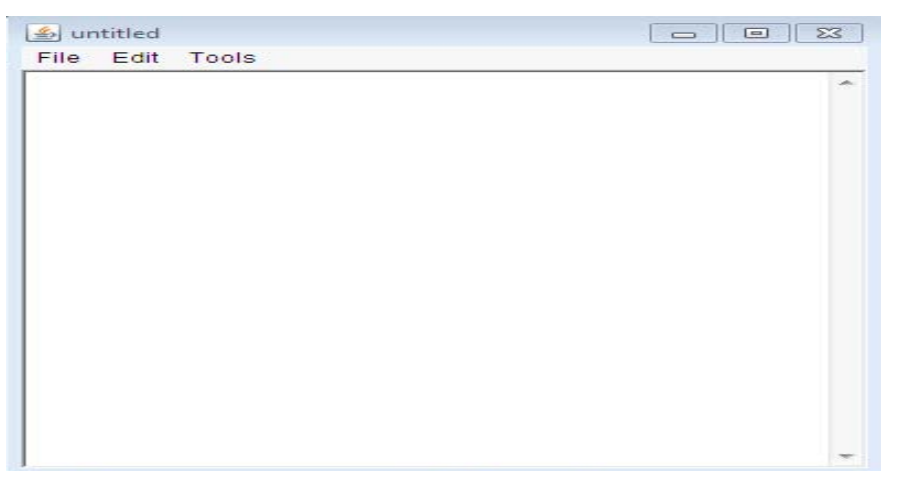

Fig 2. Snapshot of application 


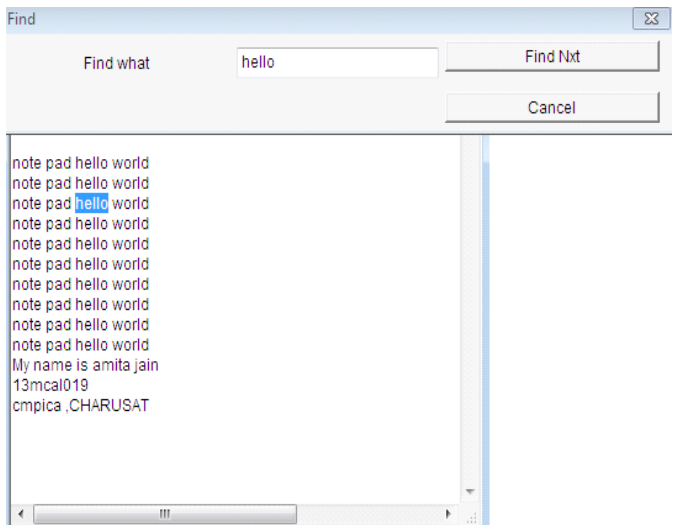

Fig 3. Snapshot of functionality "Find" They have performed manual testing and they have made test cases for the following functionalities

- new

- open

- $\quad$ save

- $\quad$ save as

- exit

- $\quad$ find

- $\quad$ find and replace

- $\quad$ find and replace all

Students have made the test case for each functionality, as an sample one functionality is listed below in Figure 4,

\begin{tabular}{|c|c|c|}
\hline Tesscase Input & Expected Result & Actual Result \\
\hline tcl blank page & Blank page & Blank page \\
\hline tc2 some text & Visible & Visible \\
\hline to 3 close & Ask to save & Ask to save dialog \\
\hline tct open another & Ask to save & Ask to save \\
\hline tof open and press no & Don't save & Open another file \\
\hline
\end{tabular}

Fig 4. Snapshot of Test case for "New" functionality.

learning can help the student to develop their creative abilities [8][9]. We have designed a new way to apply the PBL which include the following steps,

- Instructors have to provide the resources in such a way, which students can access any time, and they can learn to find their own resources based on the problem they face.

- Evaluate the case study in different phases with all the team members.

\subsubsection{Automated case study example}

The other group of students have opted for performance testing and they have measured the performance issues of their system as below, table 1 shows the http response codes which are retrieved during the access of system, table 2 shows the bandwidth usage and table 3 shows the overall utilization of resources in terms of memory and processor.

Table 1: HTTP response codes tracking for the system

\begin{tabular}{|l|l|r|c|}
\hline Code & Request & $\begin{array}{l}\text { Pag } \\
\text { es }\end{array}$ & $\begin{array}{l}\text { Hi } \\
\text { ts }\end{array}$ \\
\hline $\begin{array}{l}\text { Profil } \\
\text { e1 }\end{array}$ & - & 43 & 53 \\
\hline 200 & Profile1.All & 43 & 43 \\
\hline 200 & $\begin{array}{l}\text { Profile1.page_1: } \\
\text { http://localhost/EventManagmentSQA/ } \\
\text { Login.php }\end{array}$ & 12 & 12 \\
\hline $\begin{array}{l}\text { Profile1.page_2: } \\
\text { http://localhost/EventManagmentSQA/ } \\
\text { register.php }\end{array}$ & 12 & 12 \\
\hline $\begin{array}{l}\text { Profile1.page_3: } \\
\text { http://localhost/EventManagmentSQA/ } \\
\text { regcode.php }\end{array}$ & 10 & 10 \\
\hline $\begin{array}{l}\text { Profile1.page_4: } \\
\text { http://localhost/EventManagmentSQA/ } \\
\text { LoginCode.php }\end{array}$ & 9 & 9 \\
\hline $\begin{array}{l}\text { Foun } \\
\text { d }\end{array}$ & $\begin{array}{l}\text { Profile1.page_3: } \\
\text { http://localhost/EventManagmentSQA/ } \\
\text { regcode.php }\end{array}$ & 10 & 10 \\
\hline
\end{tabular}

Table 2: Data send and received in terms of Kbytes

\begin{tabular}{|l|l|l|l|l|l|l|l|l|l|l|l|}
\hline Pr & $0:$ & $0:$ & $0:$ & $0:$ & $0:$ & $0:$ & $0:$ & $0:$ & $0:$ & $0:$ & $\mathrm{T}$ \\
ofi & 00 & 00 & 00 & 00 & 00 & 00 & 00 & 00 & 00 & 00 & 0 \\
le & $: 0$ & $: 0$ & $: 1$ & $: 1$ & $: 2$ & $: 3$ & $: 3$ & $: 4$ & $: 4$ & $: 5$ & ta \\
& 0 & 6 & 2 & 8 & 4 & 0 & 6 & 2 & 8 & 4 & 1 \\
& - & - & - & - & - & - & - & - & - & - & \\
& $0:$ & $0:$ & $0:$ & $0:$ & $0:$ & $0:$ & $0:$ & $0:$ & $0:$ & $0:$ & \\
& 00 & 00 & 00 & 00 & 00 & 00 & 00 & 00 & 00 & 01 & \\
& $: 0$ & $: 1$ & $: 1$ & $: 2$ & $: 3$ & $: 3$ & $: 4$ & $: 4$ & $: 5$ & $: 0$ & \\
& 6 & 2 & 8 & 4 & 0 & 6 & 2 & 8 & 4 & 0 & \\
\hline Pr & 10 & 0 & 0. & 2. & 3. & 1. & 2. & 2. & 1. & 2. & 2 \\
ofi & .1 & & 60 & 09 & 51 & 73 & 91 & 27 & 20 & 98 & 7 \\
le & & & & & & & & & & &. \\
1 & & & & & & & & & & & 4 \\
\hline To & 10 & 0 & 0. & 2. & 3. & 1. & 2. & 2. & 1. & 2. & 2 \\
tal & .1 & & 60 & 09 & 51 & 73 & 91 & 27 & 20 & 98 & 7 \\
& & & & & & & & & & &. \\
& & & & & & & & & & & 4 \\
\hline
\end{tabular}

\section{KBytes received}

\begin{tabular}{|l|l|l|l|l|l|l|l|l|l|l|l|}
\hline Pr & $0:$ & $0:$ & $0:$ & $0:$ & $0:$ & $0:$ & $0:$ & $0:$ & $0:$ & $0:$ & $\mathrm{T}$ \\
ofi & 00 & 00 & 00 & 00 & 00 & 00 & 00 & 00 & 00 & 00 & 0 \\
le & $: 0$ & $: 0$ & $: 1$ & $: 1$ & $: 2$ & $: 3$ & $: 3$ & $: 4$ & $: 4$ & $: 5$ & ta \\
& 0 & 6 & 2 & 8 & 4 & 0 & 6 & 2 & 8 & 4 & 1 \\
& - & - & - & - & - & - & - & - & - & - & \\
& $0:$ & $0:$ & $0:$ & $0:$ & $0:$ & $0:$ & $0:$ & $0:$ & $0:$ & $0:$ & \\
& 00 & 00 & 00 & 00 & 00 & 00 & 00 & 00 & 00 & 01 & \\
& $: 0$ & $: 1$ & $: 1$ & $: 2$ & $: 3$ & $: 3$ & $: 4$ & $: 4$ & $: 5$ & $: 0$ & \\
& 6 & 2 & 8 & 4 & 0 & 6 & 2 & 8 & 4 & 0 & \\
\hline Pr & 13 & 0 & 0. & 2. & 4. & 1. & 4. & 1. & 0. & 4. & 3 \\
ofi & .4 & & 44 & 63 & 87 & 37 & 43 & 86 & 88 & 38 & 4 \\
le & & & & & & & & & & & \\
1 & & & & & & & & & & & 2 \\
\hline
\end{tabular}




\begin{tabular}{|c|l|l|l|l|l|l|l|l|l|l|l|}
\hline To & 13 & 0 & 0. & 2. & 4. & 1. & 4. & 1. & 0. & 4. & 3 \\
tal & .4 & & 44 & 63 & 87 & 37 & 43 & 86 & 88 & 38 & 4 \\
& & & & & & & & & & & 2 \\
\hline
\end{tabular}

Table 3: Resource utilization

Utilization, \%

\begin{tabular}{|l|l|l|l|l|l|l|l|l|l|l|l|l|}
\hline N & Ut & $0:$ & $0:$ & $0:$ & $0:$ & $0:$ & $0:$ & $0:$ & $0:$ & $0:$ & $0:$ & T \\
a & ili & 0 & 0 & 0 & 0 & 0 & 0 & 0 & 0 & 0 & 0 & ot \\
m & za & $0:$ & $0:$ & $0:$ & $0:$ & $0:$ & $0:$ & $0:$ & $0:$ & $0:$ & $0:$ & al \\
e & tio & 0 & 0 & 1 & 1 & 2 & 3 & 3 & 4 & 4 & 5 & \\
& n & 0 & 6 & 2 & 8 & 4 & 0 & 6 & 2 & 8 & 4 & \\
& & - & - & - & - & - & - & - & - & - & - & \\
& & $0:$ & $0:$ & $0:$ & $0:$ & $0:$ & $0:$ & $0:$ & $0:$ & $0:$ & $0:$ & \\
& & 0 & 0 & 0 & 0 & 0 & 0 & 0 & 0 & 0 & 0 & \\
& & $0:$ & $0:$ & $0:$ & $0:$ & $0:$ & $0:$ & $0:$ & $0:$ & $0:$ & $1:$ & \\
& & 6 & 2 & 8 & 4 & 0 & 6 & 2 & 8 & 4 & 0 & \\
\hline A & C & 3 & 1 & 2 & 1 & 1 & 1 & 1 & 1 & 1 & 1 & 2 \\
d & P & 0 & 8 & 1 & 9 & 9 & 9 & 8 & 9 & 8 & 7 & 0 \\
m & U & & & & & & & & & & & \\
i & & & & & & & & & & & & \\
n & & & & & & & & & & & & \\
\hline & M & 3 & 3 & 3 & 3 & 3 & 3 & 3 & 3 & 3 & 3 & 3 \\
& e & 5 & 5 & 5 & 5 & 5 & 5 & 5 & 5 & 5 & 5 & 5 \\
& m & 8( & 9( & 9( & 8( & 8( & 7( & 7( & 7( & 7( & 7( & 7( \\
& or & 1 & 1 & 1 & 1 & 1 & 1 & 1 & 1 & 1 & 1 & 1 \\
& y & $7)$ & $7)$ & $7)$ & $7)$ & $7)$ & $7)$ & $7)$ & $7)$ & $7)$ & $7)$ & $7)$ \\
& M & & & & & & & & & & & \\
& b( & & & & & & & & & & & \\
& $\%$ & & & & & & & & & & & \\
& ) & & & & & & & & & & & \\
\hline
\end{tabular}

\section{BENEFITS OF CASE STUDY BASED LEARNING}

In the conceptual subjects like Software Quality Assurance, it is difficult to apply the concepts directly in laboratory hours, apart from practical and theory session, case study based learning allows to creatively apply the concepts learnt in an effective manner. Using this approach as several benefits as below,

- Students gained insight of the subject.

- They learnt to work in team of heterogeneous students.

- Able to apply all the concepts at different groups of case study.

- Gained self-confidence about the subject.

- Applied the concepts in a creative and distinct way.

- Weaker students worked in team and improved their performance.

\section{CONCLUSION}

In this paper we describe the characteristics of current students, explain the importance of problem based learning and show the reasons why we need to apply this approach. The changes in field of software are very fast, in this situation students has to have a background to do self learning. The paper emphasizes the use of case study based approach to create interest in the subject and derive selflearning capability among the students.

\section{REFERENCES}

[1] Claire H. Major , Betsy Palmer ,’Assessing the Effectiveness of Problem-Based Learning in Higher Education: Lessons from the Literature”, Spring 2001: Volume 5, Issue 1.

[2] Yusuf, M.O.,Information and communication education: Analyzing the Nigerian national policy for information technology. International Education Journal Vol. 6 No. (3), Pp; 316-321,2005.

[3] Al-Ansari, H., Internet use by the faculty members of Kuwait University. The Electronic Library Vol.24, No. (6), Pp; 791-803,2006.

[4] Andrew Elbert Walker, Heather Leary, Cindy E. HmeloSilver, Peggy A. Ertmer, Essential Readings in Problembased Learning, Purdue University Press,2015.

[5] Cindy E. Hmelo-Silver, Problem-Based Learning: What and How Do Students Learn? Educational Psychology Review, Vol. 16, No. 3, September 2004.

[6] Herreid CF, Schiller NA, Herreid KF, Wright C. In case you are interested: results of a survey of case study teachers. J Col Sci Teach. 2011;40(4):76-80.

[7] Bonney KM. An argument and plan for promoting the teaching and learning of neglected tropical diseases. J. Microbiol. Biol. Educ. 2013;14(2):183-188. doi: 10.1128/jmbe.v14i2.631

[8] Herreid CF. Case studies in science-a novel method of science education. J Col Sci Teach. 1994;23(4):221-229.

[9] Flynn AE, Klein JD. The influence of discussion groups in a case-based learning environment. Educ Tech Res Dev. 2001;49(3):71-86. doi: 10.1007/BF02504916.

[10] Murray-Nseula M. Incorporating case studies into an undergraduate genetics course. J. Schol. Teach. Learn. 2011;11(3):75-85.

[11] Pintrich PR, Schunk DH. Motivation in education: theory, research, and applications. Merrill Prentice-Hall; Upper Saddle River, NJ: 2002.

[12] Yadav A, et al. Teaching science with case studies: a national survey of faculty perceptions of the benefits and challenges of using cases. J Col Sci Teach. 2007;37(1):34-38

[13] Barrows, H. S. (1996). Problem-based learning in medicine and beyond. In L. Wilkerson \& W. H.Gijselaers (Eds.), New directions for teaching and learning: Vol. 68. Bringing

[14] Boud, D. (1987). Problem-based learning in perspective. In D. Boud (Ed.), Problem based learning in education for the professions ,. Sydney: Higher Education Research and Development Society of Australia

[15] http://ldt.stanford.edu/ jeepark/jeepark+portfolio/PBL/wh atis3.htm 